\title{
Optimising the use of plastic protective covers in field grown melon on a farm scale
}

\author{
Paolo Benincasa, ${ }^{1}$ Andrea Massoli, ${ }^{2}$ Livia Polegri,, ${ }^{2}$ Luciano Concezzi, ${ }^{2}$ Andrea Onofri, ${ }^{1}$ \\ Francesco Tei $^{1}$ \\ 'Dipartimento di Scienze Agrarie, Alimentari ed Ambientali, Università di Perugia; \\ 23A-PTA Parco Tecnologico Agroalimentare dell'Umbria, Pantalla di Todi (PG), Italy
}

\begin{abstract}
This in-farm research study was aimed at evaluating new strategies in the use of plastic protective covers in field grown melon in order to expand the production period and reduce costs. Four experiments were set up in 2010 and repeated in 2011 in Central Italy, in an inland region with a temperate climate. We evaluated: i) the use of high tunnels for two growing cycles per year, i.e. for very early and very late production (target transplanting in late winter and mid-summer, respectively), for either one year or two consecutive years, and the use of grafted plants in the second year as an alternative to normal plants to prevent soil born diseases; ii) the use of ethylene-vinyl-acetate film low tunnels alone or combined with non-woven floating row covers for transplanting in early spring; iii) the use of non-woven low tunnels for transplanting in mid-spring; iv) the use of biodegradable and conventional polyethylene ground mulch films, both in the presence of nonwoven low tunnels. As far as the non-woven cover is concerned, we adopted the strategy of removing later with respect to usual practices, i.e. ten days after the onset of first pistillate flowers. This was based on the evidence that covers hamper honeybee circulation, which may be exploited on a farm-scale to delay pollination until an adequate number of pistillate flowers set, in order to shorten scaled fruit ripening
\end{abstract}

Correspondence: Paolo Benincasa, Dipartimento di Scienze Agrarie, Alimentari ed Ambientali, Università di Perugia, Borgo XX Giugno 74, 06121 Perugia, Italy.

Tel. +39.075.5856325 - Fax: +39.075 .5856344 .

E-mail: paolo.benincasa@unipg.it

Key words: tunnel, row cover, mulch, non-woven, ripening, harvest.

Funding: research funded by the Piano di Sviluppo Rurale della Regione Umbria 2007-2012, Misura 1.2.4.

Conference presentation: SIA XLII Congress, Reggio Calabria, 2013.

Received for publication: 3 October 2013.

Revision received: 19 November 2013.

Accepted for publication: 23 November 2013.

(O) Copyright P. Benincasa et al., 2014

Licensee PAGEPress, Italy

Italian Journal of Agronomy 2014; 9:556

doi:10.4081/ija.2014.556

This article is distributed under the terms of the Creative Commons Attribution Noncommercial License (by-nc 3.0) which permits any noncommercial use, distribution, and reproduction in any medium, provided the original author(s) and source are credited. and harvest. Our results demonstrate that high tunnels may be used for at least four consecutive melon growing cycles (early and late productions for two years) with good off-season yields and no appreciable drawbacks in terms of disease scale-up, irrespective of the use of normal or grafted plants. The non-woven low tunnel was effective in hampering honeybee circulation and its delayed removal allowed the harvest period to be halved, a more uniform fruit size to be obtained, and labour productivity of harvest to be increased. This had positive implications on the management of irrigation and chemical disease control close to the harvest period, and on the management of harvest and post-harvest operation schedules, including fruit processing, packaging and delivery to markets. In the presence of a non-woven low tunnel, there was no substantial difference in the biodegradable mulch compared to other mulches in terms of effects on harvest dates, yield and weed control, so that its use can be cost-effective and convenient provided that costs are not higher than those for traditional polyethylene films and their usage/disposal.

\section{Introduction}

Achieving off-season melon production with low cultivation costs represents a key factor for farmers to increase their net income (Ibarra et al., 2001; Jett, 2006). The main costs in melon production are represented by plastic covers for protected cultivation and by scaled handharvest (Waterer, 2003; Yilmaz et al., 2011).

High tunnels are essential for very early and late production, but they should be used for more than one growing cycle in order to reduce amortisation costs, although this is expected to increase the incidence of soilborn diseases (Belisario et al., 1998), especially in the absence of crop rotation, which may be the case on a very specialised melon farm. However, solarisation, cultivar disease resistance, and the use of grafted plants may help limit these problems (Alan et al., 2007; Castronuovo et al., 2005; Tamietti and Valentino, 2006; Trionfetti Nisini et al., 2002). In contrast to high tunnels, either low tunnels, floating row covers or ground mulches are usually disposable and thus expensive (cost of material, setup and disposal), although biodegradable films are now available which would help avoid at least usage/disposal costs (Filippi $e t$ al., 2011; Vox et al., 2005; Waterer, 2010). In any case, the profit margin of using plastic protections just for a warming effect may be quite small, particularly when considering that cheap products may often be gathered from nearby cultivation areas with milder spring climates.

As far as the cost of harvest is concerned, this is generally high because fruit ripening is very scaled in a melon crop and the harvest period may last more than one month, with daily transit and a lot of time lost at each transit to search for and pick ripe fruit. Scaled fruit ripening is a consequence of scaled pistillate flower set and crosspollination by honeybees (Vaissiere and Froissart, 1996). In this regard, plastic covers are usually considered to be an obstacle to honeybee cir- 
culation and, for this reason, it is suggested that they are removed as soon as first pistillate flowers appear in the crop (Vaissiere and Froissart, 1996). On the contrary, we hypothesise that plastic covers could be used as a means to hamper honeybee circulation until an adequate number of pistillate flowers set. In this way, when covers are removed, flowers could be pollinated all at the same time and fruit would ripen together, with expected benefits in terms of harvest management for the entire farm. This should also help improve the profitability of plastic protective covers.

To our knowledge, no scientific literature is available that accurately defines the effects of delayed cover removal on melon yield and harvest management ona farm scale. A few papers have dealt with this strategy in melon, although these studies had different aims. For example, Eischen et al. (1994) mainly aimed at reducing exposure of honeybee to insecticides, Rojas et al. (2011) aimed at suppressing bacterial wilt, and Long et al. (2004) aimed to manipulate source-sink relationships and study effects on fruit total soluble sugars. This work aims to evaluate the feasibility of new production strategies based on the use of plastic protective covers on a farm representative of intensive melon cultivation in a temperate region, taking into account agronomical effects and management implications.

\section{Materials and methods}

Field experiments were carried out on rockmelon (Cucumis melo L. var. reticulatus) crops grown by the TopMelon company, representative of intensive melon growing, with over 200 hectares cultivated in Central Italy and 10,000 tons of fruits produced, processed and packaged on the farm per year between June and October. The experimental site $\left(42^{\circ} 53^{\prime}\right.$ $\mathrm{N}, 12^{\circ} 24^{\prime} \mathrm{E}, 165 \mathrm{~m}$ asl) is representative of an inland region with a temperate climate, where morning temperature in spring may drop below $0^{\circ} \mathrm{C}$ until the beginning of April and below $5^{\circ} \mathrm{C}$ until mid-May. For this reason, melon can be reasonably grown in spring only by using protective covers for at least the early phases of the cycle. Four in-farm experiments were set up in 2010 and repeated in 2011, in plain and well-drained fields, with loam soil that had hosted wheat as previous crop and neither melon nor other Cucurbitaceae, nor Solanaceae crop species in the previous four years. Apart from experimental treatments, ordinary cultivation techniques were adopted in all experiments: all crops were transplanted on raised beds at a density of 0.5 plants $\mathrm{m}^{-2}$, with rows $2 \mathrm{~m}$ apart, water and nutrient requirements were fully covered by fertigation, while weeds overcoming ground mulch control, pests and fungal diseases, in particular downy mildew, were chemically controlled as needed. Weather data were automatically recorded by a local weather station. The four experiments for each year were scheduled according to different transplanting dates in order to represent all cropping periods from early to late production. Four types of crop protection measures were evaluated: i) high tunnels; ii) film and non-woven low tunnels; iii) non-woven floating row covers; iv) ground mulches. These crop protection measures were used in different combinations, with the main aim of obtaining different degrees of warming effects, according to the growing period (Table 1). In all experiments, non-woven cover (low tunnel or floating row cover) was removed ten days after the first pistillate flowers set on $50 \%$ of plants, which represents roughly a 10-day delay with respect to the recommendation commonly found in literature (Eischen et al., 1994; Long et al., 2004).

\section{Experiment with high tunnel for very early and very late production}

The following plastic protection was used: a high tunnel $5.0 \mathrm{~m}$ wide $\times 2.5 \mathrm{~m}$ high $\times 40 \mathrm{~m}$ long, covered by an ethyl-vinyl-acetate (EVA) film
[Patilux, P.A.T.I., San Zenone degli Ezzelini (TV), Italy] $0.15 \mathrm{~mm}$ thick + low tunnel $1.0 \mathrm{~m}$ wide $\times 0.5 \mathrm{~m}$ high covered with non-woven $(17 \mathrm{~g}$ $\mathrm{m}^{-2}, 25 \%$ shade) + ground mulch with a green polyethylene (PE) film $0.05 \mathrm{~mm}$ thick.

The basic experimental unit for this design was represented by a high tunnel (Figure 1). Three replicate high tunnels were set up in 2010, wherein the early crop (cv. Macigno, Clause) was planted on 3 April (a 2-week delay from planned mid-March transplanting was caused by prolonged rainy weather). The non-woven low tunnel was removed on 8 May 2010.

After the harvest of this early crop, residues were removed and solarisation was performed throughout July by sealing high tunnels open and watering repeatedly inside. The late crop (cv. Tuareg, Syngenta) was planted on 6 August 2010. The non-woven low tunnel was removed on 2 September 2010.
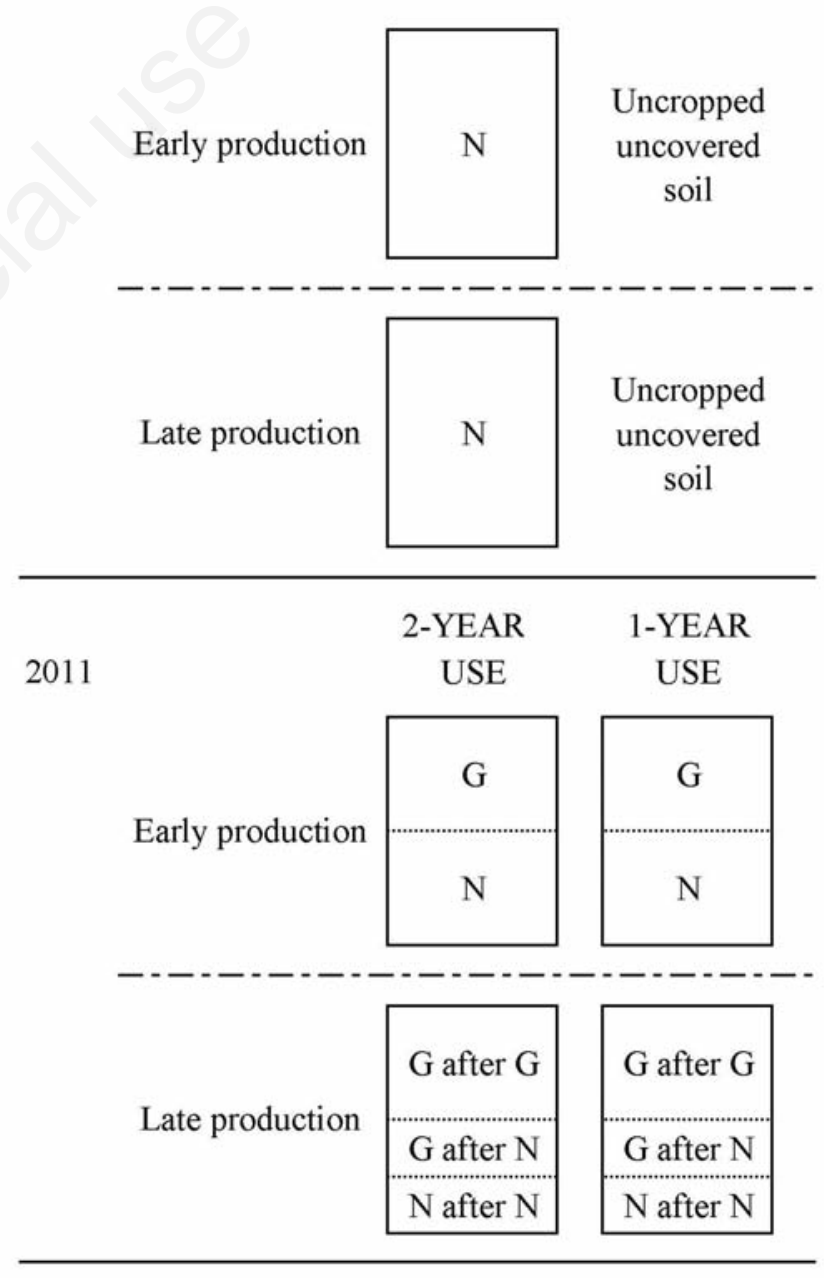

Figure 1. Sequence of early and late melon crops in 2010 (preliminary year) and 2011 for Experiment no. 1. The figure refers to one three blocks, consisting of one tunnel (rectangle) in 2010 and two tunnels in 2011. G, grafted plants; N, normal plants. See text for details. 
In the following year (2011), on the uncropped spaces left alongside each tunnel (Figure 1), three new high tunnels were set up in order to compare 1-year use and 2-year use. Both the 2011 tunnels and the 2010 tunnels were split into two parts and the early crop (cv. Macigno) was planted on 18 March both as normal (N) plants and as grafted (G) plants (onto rootstocks of cv Dinero, S\&G, Syngenta). The non-woven low tunnel was removed on 24 April 2011.

After crop harvest, residue removal and solarisation (as in the previous year) were performed and the late crop was planted on 27 July 2011 using the cultivar Magritte (Nunhems) as normal (N) or grafted (G) plants (onto cv. Dinero rootstocks). Considering the early production of 2011 (Figure 1), the design was arranged so that grafted plants were transplanted both after grafted plants (G after $\mathbf{G}$ ) and after normal plants (G after $\mathrm{N}$ ), while normal plants were transplanted only after normal plants ( $\mathrm{N}$ after $\mathrm{N}$ ). The non-woven low tunnel was removed on 23 August 2011.

Early and late production were regarded as two different experiments and, for both, 2010 was regarded as preliminary. With reference to early crop production, the experimental design in 2011 comprised a factorial combination of two experimental treatments, i.e. number-ofyears use for tunnels ( $1 v s 2$ ) and type of transplant ( $\mathrm{N} v s \mathrm{G})$, laid down according to a split-plot design, with high tunnels as the main plots and type of plants as sub-plots (Figure 1). In the late production of 2011, the experimental design was again a split-plot, with tunnels of 1- and 2year use as main plots and type of transplant placement (G after G, G after $\mathrm{N}$ and $\mathrm{N}$ after $\mathrm{N}$ ) as sub-plots (Figure 1). The sub-plot consisted of a minimum of 2 rows of 10 plants each.

\section{Experiment with ethyl-vinyl-acetate film low tunnel alone or combined with non-woven floating row cover for target transplanting in early spring}

The following plastic protection was common to all treatments: a low tunnel $1.0 \mathrm{~m}$ wide $\times 0.5 \mathrm{~m}$ high covered with an EVA film $0.05 \mathrm{~mm}$ thick + ground mulch with a grey PE film $0.05 \mathrm{~mm}$ thick in 2010 and $0.08 \mathrm{~mm}$ thick in 2011. In a randomised complete block design with three replicates, two treatments were compared: presence or absence of nonwoven (17 $\mathrm{g} \mathrm{m}^{-2}, 25 \%$ shade) floating row cover laid over plants below the EVA film. The crop was planted on 9 April 2010 and 1 April 2011; the cultivar Macigno was used in both years. The EVA film low tunnel was removed together with the non-woven floating row cover on 20 May
2010 and 12 May 2011. The experimental plot consisted of 2 rows of 20 plants each.

\section{Experiment with or without non-woven low tunnel for target transplanting in mid-spring}

In a randomised complete block design with three replicates, two treat-
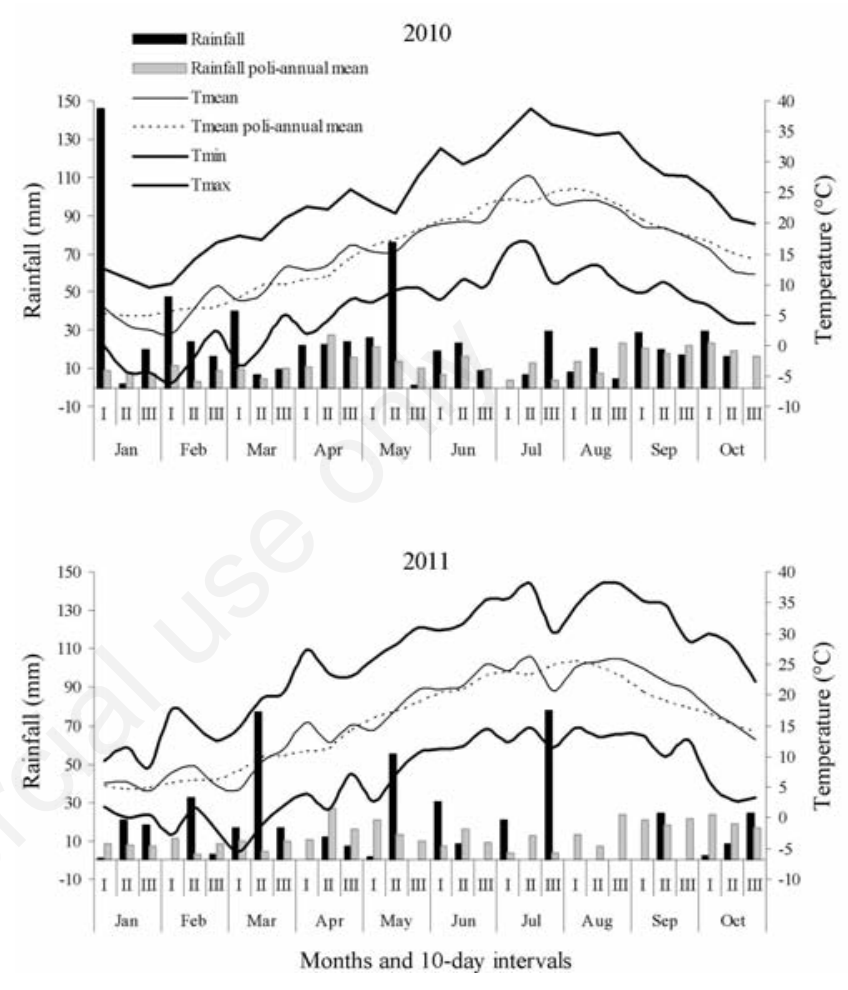

Figure 2. Ten-day total rainfall and average of daily minimum (Tmin), maximum (Tmax) and mean (Tmean) temperature, in the period January-October 2010 (above) and 2011 (below), as recorded at the experimental site. Poli-annual means (50 years) are reported as reference.

Table 1. Main traits of the four experiments set up in 2010 and repeated in 2011. For Experiment no. 1, comparisons were carried out only in 2011, while 2010 represented a preliminary year. See text for details.

\begin{tabular}{|c|c|c|c|}
\hline Experiment no. & Protection common to all treatments & Target transplanting date & Comparisons \\
\hline 1 & $\begin{array}{l}\text { EVA film high tunnel + non-woven low tunnel } \\
+ \text { PE ground mulch }\end{array}$ & $\begin{array}{l}\text { Late winter } \\
\text { (earliest production) } \\
\text { Mid-summer } \\
\text { (latest production) }\end{array}$ & $\begin{array}{l}\text { 1-year vs 2-year use for } \\
\text { tunnels; } \\
\text { G vs N plants } \\
\text { 1-year us 2-year use for tunnels; } \\
\text { G after G vs G after N vs N after N }\end{array}$ \\
\hline 2 & EVA film low tunnel + PE ground mulch & Early spring & Presence $v s$ absence of non-woven floating row cover \\
\hline 3 & PE ground mulch & Mid-spring & Presence $v s$ absence of non-woven low tunnel \\
\hline 4 & Non-woven low tunnel & Mid-spring & $\begin{array}{l}\text { Among ground mulches: } \\
\text { black PE } v s \\
\text { grey PE } v s \\
\text { green PE } v s \\
\text { grey biodegradable }\end{array}$ \\
\hline
\end{tabular}

EVA, ethyl-vinyl-acetate; PE, green polyethylene; G, grafted plants; N, normal plants. 
ments were compared: presence or absence of non-woven $\left(17 \mathrm{~g} \mathrm{~m}^{-2}, 25 \%\right.$ shade) low tunnel, labelled as NWyes and NWno, respectively. All treatments were ground mulched with a grey 0.05 thick PE film. The crop was planted on 25 May 2010 (cv. Thales, Syngenta) and 18 May 2011 (cv. Caldeo, Syngenta). The non-woven low tunnel was removed on 28 June 2010 and 23 June 2011, ten days after first pistillate flower set on $50 \%$ of plants. The experimental plot consisted of 2 rows of 20 plants each.

\section{Experiment with different ground mulches for target transplanting in mid spring}

In a randomised complete block design with three replicates, the following four ground mulch treatments were compared: black, grey and green PE films $0.05 \mathrm{~mm}$ thick, biodegradable grey film $0.012 \mathrm{~mm}$ thick. The crop was planted on 17 May 2010 (cv. Sogno, Clause) and 27 May 2011 (cv. Globstar, Syngenta). In all treatments, an early non-woven ( $17 \mathrm{~g} \mathrm{~m}^{-2}, 25 \%$ shade) low tunnel was used, which was removed on 17 June 2010 and 29 June 2011. The experimental plot consisted of 2 rows of 20 plants each.

We recorded the dates of first pistillate flower set on $50 \%$ of plants, dates of harvest transits, weed density, incidence rate of diseases, yield harvested at any passage and total, number of fruits per plant, size and weight of individual fruits. According to the ordinary farm management practices, the beginning and duration of the harvest period were decided by the presence of enough ripe fruits to make harvesting worthwhile. Therefore, the occasional presence of very early and very late ripe fruits was neglected.

In Experiment no. 3, fruit ${ }^{\circ}$ Brix was measured on 5 fruits per plot on a harvest date common to both treatments (12 August 2010 and 3 August 2011), corresponding to the beginning of harvest period for NWyes and to mid-harvest period for NWno.

Data were submitted to ANOVA according to the experimental design of any experiment by using the $R$ statistical environment ( $R$ Development Core Team, 2012).

\section{Results and discussion}

Compared to long-term averages, the weather (Figure 2) in 2010 was rainy in winter and spring, warm early in spring, close to average in summer (apart from July, that was particularly hot). In 2011, it was close-to-average in terms of rainfall, but mostly warmer than usual in spring and summer, although two very cold morning periods occurred between mid-April and mid-May $\left(1.4^{\circ} \mathrm{C}\right.$ average Tmin between 11 and 20 April, $2.6^{\circ} \mathrm{C}$ between 1 and 10 May).

\section{Experiment with high tunnel for very early and very late production}

During the preliminary year (2010), the high tunnel did not allow a very early production to be obtained (Experiment no. 1; Table 2). The first harvest was on 25 June, at least two weeks later than wished, but this was caused by the delay of tunnel setup and planting consequent to the abundant and prolonged winter rainfall. The harvest period lasted only one week, which may be attributed to the delayed removal of non-woven low tunnel, as will be shown later on with reference to

Table 2. Harvest time, total yield and number of fruits harvested per plant for very early and very production of melon grown under high tunnels in 2010. Standard errors are in brackets.

\begin{tabular}{lcccc}
$\begin{array}{l}\text { Production } \\
\text { period }\end{array}$ & $\begin{array}{c}\text { First } \\
\text { harvest } \\
\text { Date }\end{array}$ & $\begin{array}{c}\text { Last } \\
\text { harvest } \\
\text { Date }\end{array}$ & $\begin{array}{c}\text { Total } \\
\text { yield } \\
\mathrm{t} \mathrm{ha}^{-1}\end{array}$ & $\begin{array}{c}\text { Fruits per } \\
\text { plant } \\
\text { No. }\end{array}$ \\
Early & 25 Jun & 1 July & $38.6(2.33)$ & $6.0(0.29)$ \\
Late & 21 Oct & 22 Oct & $30.7(8.36)$ & $7.4(2.38)$ \\
\hline
\end{tabular}

Table 3. Harvest time, total yield and number of fruits harvested per plant in early production of melon grown in 2011 under high tunnels used for one or two consecutive years and by transplanting normal or grafted plants (see text for further details). Standard errors are in brackets. No significant effects and interactions were observed in ANOVA, apart from a significant interaction Number-of-yearsuse $x$ Type-of-transplants on total yield $(\mathrm{P}<0.01)$.

\begin{tabular}{|c|c|c|c|c|c|}
\hline Number-of-years-use & Type of transplants & $\begin{array}{c}\text { First harvest } \\
\text { Date }\end{array}$ & $\begin{array}{l}\text { Last harvest } \\
\text { Date }\end{array}$ & $\begin{array}{c}\text { Total yield } \\
\mathrm{t} \mathrm{ha}^{-1}\end{array}$ & $\begin{array}{c}\text { Fruits per plant } \\
\text { No. }\end{array}$ \\
\hline \multirow[t]{2}{*}{1} & $\mathrm{~N}$ & 8 Jun & 14 Jun & $71.6(3.72)$ & $11.6(1.32)$ \\
\hline & G & 8 Jun & 14 Jun & $60.5(4.05)$ & $11.4(0.91)$ \\
\hline \multirow[t]{2}{*}{2} & $\mathrm{~N}$ & 8 Jun & 14 Jun & $63.3(2.37)$ & $10.3(1.02)$ \\
\hline & G & 8 Jun & 14 Jun & $70.7(6.02)$ & $13.8(0.94)$ \\
\hline
\end{tabular}

N, normal plants; G, grafted plants.

Table 4. Harvest time, total yield and number of fruits harvested per plant in late production of melon grown in 2011 under high tunnels used for one or two consecutive years and by transplanting normal plants in the part of the tunnel where normal plants had been grown for early production in 2011 ( $\mathrm{N}$ after $\mathrm{N}$ ) or grafted plants after normal plants (G after $\mathrm{N}$ ) or grafted plants after grafted plants (G after G) (see text for further details). Standard errors are in brackets. No significant effects and interactions were observed in ANOVA.

\begin{tabular}{|c|c|c|c|c|c|}
\hline Number-of-years-use & Type of transplants & $\begin{array}{c}\text { First harvest } \\
\text { Date }\end{array}$ & $\begin{array}{c}\text { Last harvest } \\
\text { Date }\end{array}$ & 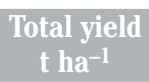 & $\begin{array}{l}\text { Fruits per plant } \\
\text { No. }\end{array}$ \\
\hline 1 & $\begin{array}{l}\mathrm{N} \text { after } \mathrm{N} \\
\mathrm{G} \text { after } \mathrm{N} \\
\mathrm{G} \text { after } \mathrm{G}\end{array}$ & $\begin{array}{l}10 \text { Oct } \\
10 \text { Oct } \\
10 \text { Oct }\end{array}$ & $\begin{array}{l}13 \text { Oct } \\
13 \text { Oct } \\
13 \text { Oct }\end{array}$ & $\begin{array}{l}30.0(2.44) \\
26.5(4.75) \\
30.6(2.12)\end{array}$ & $\begin{array}{l}5.1(0.22) \\
4.3(0.82) \\
5.0(0.15)\end{array}$ \\
\hline 2 & $\begin{array}{l}\mathrm{N} \text { after } \mathrm{N} \\
\mathrm{G} \text { after } \mathrm{N} \\
\mathrm{G} \text { after } \mathrm{G}\end{array}$ & $\begin{array}{l}10 \text { Oct } \\
10 \text { Oct } \\
10 \text { Oct }\end{array}$ & $\begin{array}{l}13 \text { Oct } \\
13 \text { Oct } \\
13 \text { Oct }\end{array}$ & $\begin{array}{l}29.8(5.15) \\
30.4(2.71) \\
33.7(2.72)\end{array}$ & $\begin{array}{l}4.8(0.80) \\
5.0(0.29) \\
5.5(0.46)\end{array}$ \\
\hline
\end{tabular}

N, normal plants; G, grafted plants. 
Experiment no. 3. The yield was not very high for high tunnel spring production (Waterer, 2003).

Late production (Experiment no. 1; Table 2) in 2010 was harvested in late October as planned, in just two days due to both the delayed removal of non-woven low tunnel and to a strong powdery mildew attack, which accelerated fruit ripening and depressed yield. No attack of other diseases (e.g. soil-born diseases) was observed in late production, which might be due to the reduction of inoculum caused by the removal of early crop residues and summer solarisation (Tamietti and Valentino, 2006).

High tunnel in 2011 allowed a very early production and high yield in all treatments, with over 10 fruits harvested per plant (Experiment no. 1; Table 3). In particular, no significant differences were observed between new tunnels ( $1^{\text {st }}$ growing cycle) and tunnels already used in the previous year $\left(3^{\text {rd }}\right.$ growing cycle, i.e. early and late cycle in 2010 and early cycle in 2011) and between normal and grafted plants. Indeed, the interaction between number-of-years-use $\times$ type-of-plant was significant in the case of yield, but it can be observed that with grafted plants, the yield with 2-year use was significantly higher than with 1-year use, while with normal plants the difference between the 1- and 2-year use was not significant. Therefore, no drawback arose from repeating the crop for three consecutive cycles, independent of the use of normal or grafted plants. As in 2010, the harvest period lasted only for one week, thanks to the delayed removal of the non-woven low tunnel.

Also late production under high tunnels in 2011 (Experiment no. 1; Table 4) was not affected by both new and old tunnels (i.e. at the $2^{\text {nd }}$ or $4^{\text {th }}$ consecutive growing cycle, considering early and late productions for 1-year or 2-year use) or by both normal and grafted plants, while, again as in 2010, the delayed removal of the non-woven low tunnel and a strong powdery mildew attack shortened harvest and reduced crop yield in all treatments.

\section{Experiment with plastic low tunnel with or without non-woven floating row cover for target transplanting in early spring}

The EVA film low tunnel (Experiment no. 2; Table 5) allowed early production, especially in 2011, when the transplanting date corresponded with the planned schedule. However, yield was lower in 2011, which can be accounted for by the earlier transplanting date and the very low minimum temperature frequently occurred between mid April and midMay (Figure 2). The presence of non-woven floating row cover did not provide any remarkable benefit in terms of either earliness and duration of the harvest period or for yield. In fact, the floating non-woven cover just laid over plants did not represent a good sealing cover so that, once the EVA film was gradually opened to avoid excess warming, it did not efficiently hamper honeybee circulation. Moreover, when performing the experiment, we realised that it was actually difficult to insert and lay the non-woven cover below the EVA film without damaging transplants. This is because the EVA film needs to be set up before transplanting in order to increase soil temperature, while the nonwoven floating row cover is laid over plants after transplanting. For these reasons, this solution does not seem to be feasible in the field.

\section{Experiment with or without non-woven low tunnel for target transplanting in mid spring}

In contrast to the results of the previous experiment, the non-woven low tunnel used for experiments transplanted in May gave important benefits in both years for reducing scaled harvest (approx. 2 weeks in NWyes vs 4 weeks in NWno), while the increase in yield $(+24 \%$ in NWyes, on average over years) was not significant (Experiment no. 3; Table 6).

In particular, the non-woven low tunnel was used to delay the start of honeybee pollination of pistillate flowers for ten days (i.e. 37 days after transplanting in NWyes $v s 27$ in NWno, as an average over the two
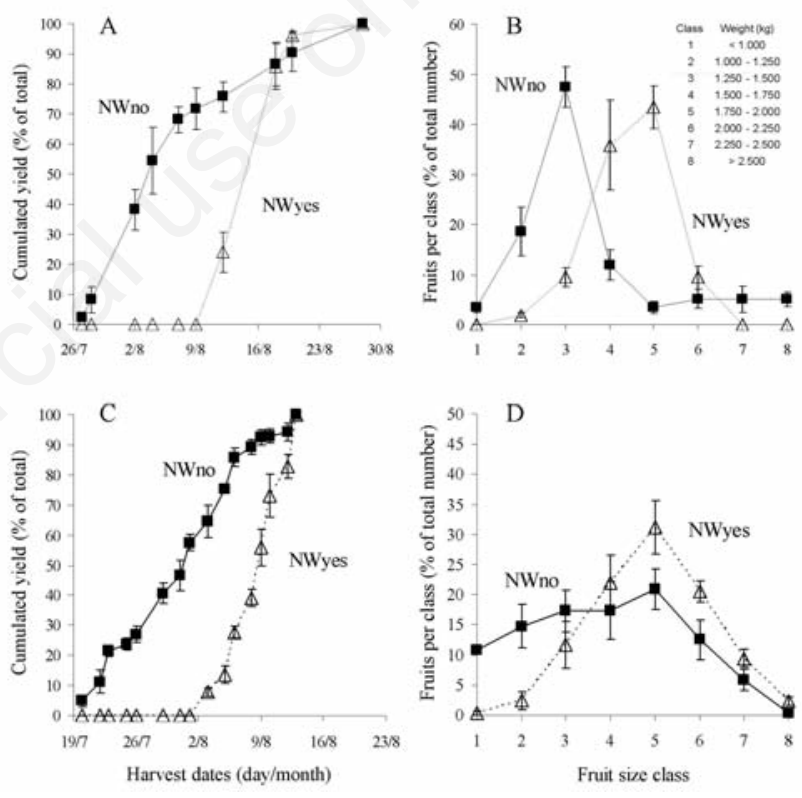

Figure 3. Cumulated yield by harvest passages in 2010 (A) and 2011 (C) and percentage distribution of the number of harvested fruits by weight class in 2010 (B) and 2011 (D) in a melon crop grown by using non-woven low tunnel (NWyes) or not (NWno) to delay honeybee pollination of pistillate flowers. Vertical bars represent SEs.

Table 5. Harvest time, total yield and number of fruits harvested per plant in early production of melon transplanted and initially grown under ethylene-vinyl-acetate film low tunnel and with non-woven floating row cover laid over transplants or without non-woven in 2010 and 2011. Standard errors are in brackets. No significant effects and interactions were observed in ANOVA, except for the Year effect $(\mathrm{P}<0.05)$ on both total yield and number of fruits per plant.

\begin{tabular}{|c|c|c|c|c|c|}
\hline Year & Non-woven use & $\begin{array}{c}\text { First harvest } \\
\text { Date }\end{array}$ & $\begin{array}{l}\text { Last harvest } \\
\text { Date }\end{array}$ & $\begin{array}{l}\text { Total yield } \\
\mathrm{t} \mathrm{ha}^{-1}\end{array}$ & $\begin{array}{c}\text { Fruits per plant } \\
\text { No. }\end{array}$ \\
\hline \multirow[t]{2}{*}{2010} & NWyes & $5 \mathrm{Jul}$ & 2 Aug & $33.1(0.71)$ & $3.7(0.08)$ \\
\hline & NWno & $5 \mathrm{Jul}$ & 2 Aug & $29.6(1.93)$ & $3.8(0.23)$ \\
\hline 2011 & $\begin{array}{l}\text { NWyes } \\
\text { NWno }\end{array}$ & $\begin{array}{l}19 \text { Jun } \\
19 \text { Jun }\end{array}$ & $\begin{array}{l}28 \text { Jun } \\
28 \text { Jun }\end{array}$ & $\begin{array}{l}20.2(2.09) \\
19.4(3.30)\end{array}$ & $\begin{array}{l}2.8(0.23) \\
2.6(0.47)\end{array}$ \\
\hline
\end{tabular}

NWyes, with non-woven floating row cover laid over transplants; NWno, without non-woven. 
years), which delayed first harvest but did not affect the date of last harvest (Figure $3 \mathrm{~A}$ and $\mathrm{C}$ ) and determined harvested fruits of greater and more uniform size (Figure 3B and D). This seems in contrast to Long et al. (2004) who found that delaying opening of net cover sides increased fruit number per plant but decreased fruit size. However, these authors reported a greater delay in pollination (14 days after first fruit set) and this could explain the differences with our results. Indeed, Eischen et al. (1994) recorded heavier fruits when cover removal was delayed six days after the onset of pistillate flowering, while they observed null to opposite effect with 12 days delay. It might also be objected that non-woven cover affected light availability and other micro-climatic factors as compared to the uncovered control. However, no effects on yield level and date of final harvest were observed (as mentioned above) and, furthermore, the use of nonwoven cover with non-delayed removal for transplanting in the second half of May would not be an interesting option in practice, because no warming effects are generally needed in that period. The shortening of the harvest period and the greater and more uniform fruit size gave further benefits some of which were actually observed and some may be easily deduced. Among these, we observed an increased labour productivity of harvest, because less transits (about half in NWyes as compared to NWno in the two years) were needed to harvest the whole yield (Figure 3A and $\mathrm{C}$ ) and a higher number of fruits were harvested at any one passage (from double in 2010 to triple in 2011 as an average in NWyes as compared to NWno; i.e. combine data on the number of fruits in Table 6 and number of harvest transits in Figure 3A and C) with less time wasted to search, check and pick ripe fruits. In fact, almost the same time was needed for all transits independently of the number of fruits harvested. Irrigation management was also improved because in NWyes irrigation could be stopped definitively approximately two weeks before the first harvest, while in NWno, where harvest period lasted approximately four weeks, irrigation had to be continued almost until the first harvest transit in order to provide water for late ripening fruits. This was expected to improve also fruit quality (higher Brix, better preservability) of NWyes, at least as compared to first harvested fruits of NWno, although Long et al. (2004) found that delaying pollination for 14 days after first fruit set decreased fruit total soluble sugars. Indeed, our single sampling carried out at the beginning of harvest of NWyes (i.e. approx. mid-harvest period of NWno) was not able to detect any difference for ${ }^{\circ}$ Brix, which was 13.4 in 2010 and 14.0 in 2011, as an average of the two treatments. Further investigation is needed to focus on the effect of this technique on fruit quality.

Similarly, a better management of chemical control against diseases can be assumed. In fact, with a longer harvest period, chemicals need to be used close to first harvest as they are aim to defend the crop until late fruits ripen. This in general may imply a higher workload for workers and greater effect on consumers, as well as for honeybees still pollinating late onset flowers. On the contrary, in non-woven covered crops where the harvest period is shortened by delaying first harvest, there is likely to be less need for chemicals close to the first harvest. Other important benefits of a shortened harvest period were better scheduling of fields to be harvested and of labour to be assigned to harvest and post-harvest operations, which implies benefits in the management of fruit processing, packaging and delivery to markets, together with better in-farm product traceability.

\section{Experiment with different ground mulches for target transplanting in mid-spring}

With regard to the experiments aimed at evaluating different ground mulches, there was no effect of treatments on harvest dates, not significant and not constant effects across years on yield (Table 7), and nonrelevant effects on weed control, which was successful with all mulches (data not shown). However, we can say that the biodegradable film did not differ substantially from other mulches so that its use can be considered worthwhile provided it does not cost more than traditional PE

Table 6. Harvest time, total yield and number of fruits harvested per plant in melon grown under non-woven low tunnel or not until 10 days after first pistillate flower set on $50 \%$ of plants in 2010 and 2011 . Standard errors are in brackets. No significant effects and interactions were observed in ANOVA.

\begin{tabular}{|c|c|c|c|c|c|}
\hline Year & Non-woven use & $\begin{array}{c}\text { First harvest } \\
\text { Date }\end{array}$ & $\begin{array}{c}\text { Last harvest } \\
\text { Date }\end{array}$ & $\begin{array}{c}\text { Total yield } \\
t_{\text {ha }} \text {-1 }^{-1}\end{array}$ & $\begin{array}{c}\text { Fruits per plant } \\
\text { No. }\end{array}$ \\
\hline 2010 & $\begin{array}{l}\text { NWyes } \\
\text { NWno }\end{array}$ & $\begin{array}{l}12 \text { Aug } \\
27 \mathrm{Jul}\end{array}$ & $\begin{array}{l}28 \text { Aug } \\
28 \text { Aug }\end{array}$ & $\begin{array}{l}27.6(5.33) \\
22.1(3.46)\end{array}$ & $\begin{array}{l}3.0(0.54) \\
2.9(0.44)\end{array}$ \\
\hline 2011 & $\begin{array}{l}\text { NWyes } \\
\text { NWno }\end{array}$ & $\begin{array}{l}3 \text { Aug } \\
20 \mathrm{Jul}\end{array}$ & $\begin{array}{l}13 \text { Aug } \\
13 \text { Aug }\end{array}$ & $\begin{array}{l}36.8(5.44) \\
29.7(6.58)\end{array}$ & $\begin{array}{l}4.0(0.63) \\
3.8(0.83)\end{array}$ \\
\hline
\end{tabular}

NWyes, with non-woven floating row cover laid over transplants; NWno, without non-woven.

Table 7. Harvest time, total yield and number of fruits per plant in melon grown under initial non-woven low tunnel and with different polyethylene and biodegradable ground mulches in 2010 and 2011. Standard errors are in brackets. No significant effects and interactions were observed in ANOVA, except for the Year effect $(P<0.01)$ on total yield.

\begin{tabular}{|c|c|c|c|c|c|}
\hline Year & Type of mulch & $\begin{array}{c}\text { First harvest } \\
\text { Date }\end{array}$ & $\begin{array}{c}\text { Last harvest } \\
\text { Date }\end{array}$ & 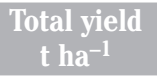 & $\begin{array}{c}\text { Fruits per plant } \\
\text { No. }\end{array}$ \\
\hline 2010 & $\begin{array}{c}\text { Black PE } \\
\text { Grey PE } \\
\text { Green PE } \\
\text { Grey BIO }\end{array}$ & $\begin{array}{l}28 \mathrm{Jul} \\
28 \mathrm{Jul} \\
28 \mathrm{Jul} \\
28 \mathrm{Jul}\end{array}$ & $\begin{array}{l}10 \text { Aug } \\
10 \text { Aug } \\
10 \text { Aug } \\
10 \text { Aug }\end{array}$ & $\begin{array}{l}29.2(1.02) \\
24.3(5.02) \\
21.9(4.03) \\
24.2(3.08)\end{array}$ & $\begin{array}{l}3.8(0.16) \\
3.2(0.68) \\
2.7(0.51) \\
3.0(0.29)\end{array}$ \\
\hline 2011 & $\begin{array}{c}\text { Black PE } \\
\text { Grey PE } \\
\text { Green PE } \\
\text { Grey BIO }\end{array}$ & $\begin{array}{l}18 \text { Aug } \\
18 \text { Aug } \\
18 \text { Aug } \\
18 \text { Aug }\end{array}$ & $\begin{array}{l}22 \text { Aug } \\
22 \text { Aug } \\
22 \text { Aug } \\
22 \text { Aug }\end{array}$ & $\begin{array}{l}19.4(0.87) \\
22.4(3.73) \\
15.8(1.53) \\
19.3(3.07)\end{array}$ & $\begin{array}{l}3.2(0.25) \\
3.9(0.69) \\
2.7(0.33) \\
3.2(0.51)\end{array}$ \\
\hline
\end{tabular}

PE, polyethylene ground mulches; BIO, biodegradable ground mulches. 
films and their usage/disposal. The fact there was no difference between mulches for harvest date is not surprising with transplanting in the second half of May and in the presence of the non-woven low tunnel, as the main warming effect may be attributed to this latter (Aquino, 2002). The lower yield obtained in 2011 was due to severe damage caused by Fusarium solani f. sp. cucurbitae Sn. et Hans.

\section{Conclusions}

Our results demonstrate that in temperate climates or wherever covers are necessary to obtain off-season melon production, high tunnels may be used for at least four consecutive melon growing cycles (early and late productions for 2 years) with no appreciable drawbacks in terms of disease scale-up, at least when soil solarisation is used during the summer season. This implies low amortisation costs which, together with good yields (in our experiments, from almost $40 \mathrm{tha}^{-1}$ to over $60 \mathrm{t} \mathrm{ha}^{-1}$ in the 2 years for early production; approx. $30 \mathrm{t} \mathrm{ha}^{-1}$ in both years for late production) and off-season production (which implies higher prices and better labour and equipment use over an expanded period) should guarantee high incomes.

The convenience of using non-woven covers for warming effects was increased by their delayed removal to hamper honeybee circulation and cause delayed and more simultaneous pollination of pistillate flowers. In this way, it was possible to shorten the harvest period by half, obtain a more uniform fruit size, and increase labour productivity of harvest. This has positive implications on the management of irrigation and chemical disease control close to the harvest period, and on the management of harvest and post-harvest operation schedules, including fruit processing, packaging and delivery to markets.

In the presence of non-woven low tunnel, there was no substantial difference between the biodegradable mulch and other mulches in terms of their effects on harvest dates, yield and weed control, so that its use can be considered convenient, provided that its costs are not higher than those for traditional polyethylene films and their usage/disposal.

\section{References}

Alan 0, Ozdemir N, Gunen Y, 2007. Effect of grafting on watermelon plant growth, yield \& quality. J. Agron. 6:362-5.

Aquino AT, Mabesa RC, 2002. Off-season production of honeydew melon
(Cucumis melo L.) using mulch and row cover. Philipp. Agric. Sci. 83:221-9.

Belisario A, Luongo L, Balmas V, Pezza L, Corazza L, 1998. Fusarium wilt of winter melon. J. Plant Pathol. 80:252.

Castronuovo D, Candido V, Margiotta S, Manera C, Miccolis V, Basile M, D'Addabbo T, 2005. Potential of a corn-starch based biodegradable plastic film for soil solarization. Acta Hort. 698:201-6.

Eischen FA, Underwood BA, Collins AM, 1994. The effect of delaying pollination on cantaloupe production. J. Apicultural Res. 33:180-4.

Filippi F, Magnani G, Guerrini S, Ranghino F, 2011. Agronomic evaluation of green biodegradable mulch on melon crop. Ital. J. Agron. 6:111-6.

Ibarra L, Flores J, Daz-Perez JC, 2001. Growth and yield of muskmelon in response to plastic mulch and row covers. Sci. Hortic. 87:139-45.

Jett LW, 2006. High tunnel melon and watermelon production. University of Missoury Extension, M173. Columbia, M0, USA. Available from: http://extension.missouri.edu/ explorepdf/manuals/ m00173.pdf Accessed: 8 July 2013.

Long RL, Walsh KB, Rogers G, Midmore DJ, 2004. Source-sink manipulation to increase melon (Cucumis melo L.) fruit biomass and soluble sugar content. Austr. J. Agric. Res. 55:1241-51.

R Development Core Team, 2012. R: A Language and Environment for Statistical Computing. R Foundation for Statistical Computing, Vienna, Austria. Available from: http://www.R-project.org/

Rojas ES, Gleason ML, Batzer JC, Duffy M, 2011. Feasibility of delaying removal of row covers to suppress bacterial wilt of muskmelon (Cucumis melo). Plant Dis. 95:729-34.

Tamietti G, Valentino D, 2006. Soil solarization as an ecological method for the control of Fusarium wilt of melon in Italy. Crop Prot. 25:389-97.

Trionfetti Nisini P, Colla G, Granati E, Temperini 0, Crinò P, Saccardo F, 2002. Rootstock resistance to fusarium wilt and effect on fruit yield and qualità of two muskmelon cultivars. Sci. Hortic. 93:281-8.

Vaissiere BE, Froissart R, 1996. Pollination of cantaloupes under spunbonded row cover by honey bees (Hymenoptera: Apidae) in West Africa. J. Econ. Entomol. 89:1213-22.

Vox G, Schettini E, Scarascia-Mugnozza G, 2005. Radiometric properties of biodegradable films for horticultural protected cultivation. Acta Hort. 691:575-982.

Waterer D, 2003. Yields and economics of high tunnels for production of warm season vegetable crops. HortTech. 13:339-43.

Waterer D, 2010. Evaluation of biodegradable mulches for production of warm-season vegetable crops. Can. J. Plant Sci. 90:737-43.

Yilmaz H, Demircan V, Kurtluk S, 2011. An economic analysis of openfield melon (Cucumis melo L.) production in Cankiri province of Turkey. Bulg. J. Agric. Sci. 17:484-90. 